\title{
NOTES AND REVIEWS
}

\author{
BOOK REVIEW: \\ INWARD LOOKING: THE IMPACT OF MIGRATION ON \\ ROMANIPE FROM THE ROMANI PERSPECTIVE
}

\begin{abstract}
Aleksandar G. Marinov. 2019. Inward Looking: The Impact of Migration on Romanipe from the Romani Perspective. Romani Studies 2. Oxford; New York, NY: Berghahn Books.
\end{abstract}

The book tackles the topic of Roma migration inside the EU, and moreover analyses how migration affects the performance of identity of Bulgarian Roma migrants. Alexandar Marinov's research is a case study based on fieldwork and looks at the narratives and experiences of Roma themselves. The book is in six main chapters, plus an introduction, conclusion and glossary. After the introduction, in which Marinov explains the focus and aims of the book and his own position as a researcher of Romani background, as well as his experiences of living abroad, the first chapter "Perceptions, Interpretations and Identities" gives a general theoretical overview of the various themes, such as migration, identity, stereotypes, othering, transnationalism and nation states, Romani identities and hybridity, Romanipe. All are relevant to the research questions and introduce the main concepts, i.e. simultaneity, desh and bidesh, network capital, internal struggle.

The second chapter, "Research Design and Methodology", expands on data collection and methods of analysis. Marinov concludes that the method of using semistructured in-depth interviews, gatekeepers and the NVivo software programme (for data analysis and coding) was fitting for his research purposes. In addition, Marinov expands on his own position and finds that although his own Romani background was mainly an aiding force in the interviews, he still feels that he is a 'partial insider' (a Roma and a migrant but not always from same Roma group or speaking the same dialect as the research participants). Marinov thoroughly analyses his methodology, also mentioning its possible limitations.

The next chapter, "Migration the Types, Reasons and Effects", is the first chapter based on empirical material and focuses on explaining the types and consequences of, and reasons for, migration among Bulgarian Roma (from Sofia, Montana and Stara Zagora). The types of migration are distinguished as migrating for seasonal unskilled or skilled work, which can change from one to another in different contexts (in addition to seasonal work itself, harsh winters combined with bad living conditions effect seasonal migration), and 'rhizomatic' migration that follows no clear pattern but is mainly caused by the view that going abroad provides better chances to achieve their goals in life. Both positive (for example better earning possibilities or future prospects for children, greater potential for self-development, better living conditions, less discrimination) and negative aspects (for example feeling alienated, failing health, discrimination, exploitation) of migration are analysed. Furthermore, in this chapter Marinov connects physical migration to imaginative, emotional and psychological migration.

In "Belonging, Attachment and Space" Marinov goes deeper into the discussion on the consequences of migration for Bulgarian Roma, explaining it from their point of view. Marinov points out the importance 
of relatives and friends for Roma migrants especially during the period shortly after arriving in the host country. In connection with this it becomes clear that Roma from the same area in Bulgaria end up in the same host countries and areas, although Marinov notes that there is a changed pattern of communication, i.e. migrants communicate with Roma from other parts of Bulgaria as well as Roma from other countries. Their feeling of 'being at home' stems from having their own Roma community in the host country. They often experience improved social status, the development of networks and human capital, and greater optimism for the future. Making and maintaining connections with other Roma becomes a more important tool for 'survival' in the host country when only negative and/or unfair treatment is experienced. Roma consider Bulgaria their real home (desh from Gardner 1993); going abroad (bidesh from ibid.) is a material necessity accompanied only by hard work and a lack of any social life. Marinov points out that a returning Romani migrant can simultaneously be in several places, using the concept of 'simultaneity' (from Levitt and Schiller 2008), something that causes an internal struggle.

In the chapter entitled "Romani Identity as Part of Migration and 'Romanipe"' Marinov explores how the identities of Roma migrants are created and discusses the flexible and changing nature of Romanipe (sets of factors, laws and behaviours that define Roma and differentiate them from non-Roma), which, although a concept used by scholars in Romani studies, does not have an agreed definition. Marinov demonstrates how Romanipe is for the Roma migrants a continuous process of becoming that is dependent on the current time, life and locations; it is open to interpretation and change. The negative and labelling view of the Roma that comes from outside causes them to hide their background or minimise behaviours that can cause them to be considered different. This external view can also become internalised, so the Roma start using the same stereotypes towards other Roma groups that non-Roma use for all Roma. This is due to rivalry, fear, mistrust and not really having experience and knowledge of the other groups. Nevertheless, as Marinov explains, some behaviours, such as stealing, being a criminal and having a poor upbringing were considered negative without connecting them to any ethnicities or groups. In this chapter Marinov uses the concepts of the 'art of living' (from Ligeois 2007) and 'selective multiculturalism' (from Gropper and Miller 2001) to aid comprehension of how Roma both maintain their Roma identity while courageously and flexibly engaging in the possibilities that host societies offer. Following on from this, the chapter discusses how migrant Roma take up new ideas, perceptions and practices from host societies according to their own needs and viewpoints. Seeing Romani identity as an 'assemblage' (Deleuze and Guattari 1987) helps us understand how migrant Roma find novel ways of celebrating their festivities, for example.

The next chapter is titled "Eye-Opening Processes: The Culture of Migration". Here, Marinov explains how what can be called a 'culture of migration' emerges. This can be clearly noticed in the smaller towns of Montana and Stara Zagora, less obviously so in the capital city Sofia. Marinov observes how Roma experiences in other countries change their perceptions. Although each migrant had his or her own unique lived experience, some patterns were shared among Roma migrants compared to non-migrant Roma. For instance, almost all Roma migrants experienced acculturation to the foreign country (getting used to different behaviour and laws and also starting to like it) and had problems associated with missing this culture once back in Bulgaria. This causes a change in the migrants' feelings of belonging and of their experience of home. In addition, because Roma migrants learned and experienced new things they also transformed 
themselves and their visions. For example, they appreciated the increased respect and dignity they experienced abroad, which were not always present after returning to Bulgaria, and this sometimes caused unease.

In "Discussion and Conclusion" Marinov combines the conclusions from previous chapters. When analysing attachment and detachment to place of origin, Marinov uses the term 'internal struggle' (caused by missing family members who stayed in Bulgaria, the feeling that the migrant's home is still Bulgaria, evaluating conditions in Bulgaria according to the new outlook gained by living in another country). Romanipe, Marinov concludes, can be defined as relating to traits stemming from stereotypes that the Roma were ashamed of, from positive traits such as traditions, language, practices and behaviours that Roma value, and from neutral feelings of belonging to one's kin group. These at times contradictory interpretations and demonstrate that there cannot be a single definition of Romanipe. In addition, Roma migration creates an interplay of Bulgarian national identity, Roma identity and host country identities. Marinov concludes the chapter with an open-ended discussion on the potential and challenges of Roma transnationalism, for example new connections arising from migration, and between different Roma groups, leads to empowerment, activism and grassroot projects, while economic crises and financial instability gives rise to competition between Roma groups.

The book offers a valuable opportunity to understand the interplay between migration and Romanipe. Through interview excerpts the reader gets a rare insight into the lives and perceptions of individual Roma migrants from Bulgaria working in the EU. It tackles a wide range of theoretical themes, as is necessary for a complex analysis, with the author managing to connect and analyse these intertwined topics skilfully. The book is generally well-structured, but due to its complexity, repetition and sub-conclusions inside the chapters at times hinder the flow slightly rather than keeping the reader on track. For further study I find that an interesting addition could be the aspects of the gender and age of the Roma migrants interviewed, and analysis of if and how this affects their experiences of migration, as this would give a more nuanced picture. In addition, as the fieldwork consisted of a pilot project during August 2012 and the main fieldwork during summer 2013, I think that to build on this research a longterm view with follow-up interviews with the same respondents would certainly add valuable layers. (Marinov himself also mentions the longitudinal aspect as a possible further direction of research, p. 60.) This book can be considered an important contribution both to migration studies, adding to the research on Roma cross border migration and free movement inside EU, and to research on Roma identities and the concept of Romanipe. Therefore, it is a highly recommended thought provoking read for everyone interested in transnational mobilities, or in any field of Romani studies.

\section{Eva-Liisa Roht-Yilmaz} (University of Tartu)

\section{References}

Deleuze, Gilles and Felix Guattari. 1987. A Thousand Plateaus: Capitalism and Schizophrenia. Minneapolis, MN; London: University of Minnesota Press.

Gardner, Katy. 1993. Desh-Bidesh: Sylheti Images of Home and Away. - Man, New Series 28 (1): 1-15. DOI: https://doi.org/10.2307/2804433.

Gropper, Rena and Carol Miller. 2001. Exploring New Worlds in American Romani Studies: Social and Cultural Attitudes among the American Mačvaia. - Romani Studies 11 (2): 81-110. DOI: https://doi.org/10.3828/ rs.2001.5.

Levitt, Peggy and Nina Glick Schiller. 2008. Conceptualizing Simultaneity: A Transnational Social Field Perspective on Society. - Rethinking Migration: New Theoretical and Empirical Perspectives, edited by Alejandro Portes and Josh DeWind. New York, NY: Berghahn Books, 181-219.

Liegeois, Jean-Pierre. 2007. Roma in Europe. 3rd edn. Strasbourg: Council of Europe Publishing. 